\title{
Evaluation of In Vitro Anti-Cancer Activity of Kukkutanakhi Guggula on Liver, Prostrate, Ovary and Renal Cancer
}

\author{
Research Article
}

Mujahid B Khan1*, Ninad Sathe², Bharat Rathi ${ }^{3}$

1. Assistant Professor, Department of Rasashastra \& Bhaishajya Kalpana,

Mahatma Gandhi Ayurved Medical College, Hospital and Research centre Salod(H), Wardha, Maharashtra.

2. Professor, PhD., Department of Rasashastra \& Bhaishajya Kalpana,

YMT Ayurvedic Medical College, Hospital PG institute, Kharghar, Navi Mumbai. Maharashtra.

3. Professor, Department of Rasashastra \& Bhaishajya Kalpana,

Mahatma Gandhi Ayurved Medical College, Hospital and Research centre Salod(H), Wardha, Maharashtra.

\begin{abstract}
The medicines prepared by using exudates of Commiphora mukul (Stocks) Hook. are described in Ayurveda under Guggula Kalpana which are among such valuable dosage forms. According to retrospective literary review, the combination of Kukkutnaki (Aspidium cicutarium Sw.) and purified Guggula(Commiphora mukul (Stocks) Hook.) was first mentioned in the book Chikitsa pradeep named as Kukkutnaki Guggula. Since last 3 decades, it was documented as an herbal drug which is used for cysts, goiter, tumors, tonsillitis, abscess, mansvaha strotas ailments, which are burning issues worldwide. Due to its observed clinical efficacy in Arbuda ( Cancer), the current in-vitro anticancer study was conducted with an aim to check its anticancer effect on human hepatoma cell line-HEPG2 of Liver; PC-3 and DU145 cancer cell lines of Prostate; Ovcar-3, A2780, SK-OV-3, PA-1 cancer cell lines of Ovary and ACHN renal cancer cell line of Kidney. The current in vitro study was conducted at ACTREC, Kharghar, Navi Mumbai. The selected cancer cell lines were procured from ATCC, USA and NCCS Pune. The Sulforhodamine B (SRB) Assay protocol was followed to observe the activity of the study drug. The positive control was Adriamycin in the study. The growth curve graphs were plotted and LC50, GI50, TGI values were calculated. Kukkutnakhi Guggula was found safe for oral administration, non- toxic at cellular level (LC50 values were $>160$ ) and have moderate activity on HEPG2, Ovcar-3, DU145, ACHN cancer cell lines and had shown negligible activity on A2780, SKOV-3, PA-1 and PC-3 cell lines. This work provides scope to study its effect on targeted cancers, specific in vivo scientific studies and human clinical trials for further researchers.
\end{abstract}

Key Words: Kukkutnakhi, Guggula, Cancer, SRB assay, In-vitro study, Cell lines.

\section{Introduction}

The different kind of natural secondary metabolites produce by the Plant Kingdom which are being inspected for their anticancer activities leading to the development of new clinical drugs.(1) In human development and well-being the rise of Cancer worldwide is a major impediment in current era. By 2030, the burden of cancer will increase to 22 million new cases each year.(2) There is need of research \& scientific documentation on newly derived and traditionally used herbal compounds and due to limitation of modern medicine $\&$ therapies, ayurvedic medicine is a ray of hope. Folklore and tribal sources

* Corresponding Author:

\section{Mujahid B Khan}

Department of Rasashastra \& Bhaishajya Kalpana,

Mahatma Gandhi Ayurved College, Hospital and

Research Centre, Salod(H), Datta Meghe Institute of Medical Sciences (Deemed to be University),

Sawangi (M) Wardha Maharashtra, India

Email Id: mujahidkhan706@gmail.com were utilized by Ayurvedic Acharyas while documenting Materia medica of Ayurveda. $(3,4)$

Kukkutnakhi is an herb grown around the monsoon and rainy seasons and found along the foot hills of Sahyadri region. $(5,6)$ It is botanically identified as Aspidium cicutarium Sw. of family Drypteridaceae. $(7,8)$ Initially it is mentioned in the text "Gharguti Aushadhe" and it is also called as Kombadnakhi, Bichava, Nirvishi and Waghchavdi. $(9,10)$ The rhizomes of this herb being used as a folklore remedy for the treatment of Shotha, Shula, Arbuda etc. successfully.(11) Guggula kalpana i.e medicines prepared by using exudates of Commiphora mukul has its own importance in the arena of ayurvedic therapeutics.(12) Kukkutnaki Guggula was selected as a study drug according to retrospective literary review from various texts and scientific magazines and it is indicated in cysts, tumors, tonsillitis, abscess, elephantiasis etc.(13) It was first mentioned in the text "Chikitsa pradeep" for various Mansavaha strotas ailments.(14) However in the text "Guggula kalpana", 
its method preparation and proportion of the ingredients is mentioned.(15)

The study drug was formulated by using authenticated Kukkutnakhi and purified Guggul in the same proportion for oral administration as per text Guggula Kalpana.(16) Current in-vitro anticancer study was conducted by following SRB assay with an aim to check anticancer effect of Kukkutnaki Guggula on human hepatoma cell line-HEPG2 of Liver; PC-3 and DU145 cancer cell lines of Prostate; Ovcar-3, A2780, SK-OV-3, PA-1 cancer cell lines of Ovary and ACHN renal cancer cell line of Kidney.

\section{Materials and Methods Material}

The selected cancer cell lines i.e human hepatoma cell line-HEPG2 of Liver; PC-3 and DU145 cancer cell lines of Prostate; Ovcar-3, A2780, SK-OV-3, PA-1 cancer cell lines of Ovary and ACHN renal cancer cell line of Kidney were procured from American Type Culture Collection (ATCC),USA and NCCS Pune. 96 well plate, $15 \mathrm{ml}$ centrifuge tubes, SRB Calorimeter, 25 $\mathrm{cm}^{2}$ tissue culture flasks, Millipore disposable filters, Liquid nitrogen container, $\mathrm{CO}_{2}$ incubator, Laminar flow hood, Haemocytometer, Biological Microscope, Drug dispensing machine, Electronic balance, Multichannel automated pipette, Elisa reader were used for in vitro study. The chemicals like SRB dye, Ethanol, TCA liquid nitrogen, DMSO, RPMI medium, DMEM were used in the current study.

\section{Method}

The current in vitro study was conducted at ACTREC (Advanced Centre for Treatment, Research and Education in Cancer), Kharghar, Navi Mumbai. The Sulforhodamine B (SRB) Assay protocol was followed to observe the activity of the study drug and Adriamycin (Doxorubicin) was used as positive control.

\section{In-Vitro Study}

The selected cancer cell lines were checked for quality control and its cryopreservation was done in Liquid nitrogen vapors and $\operatorname{DMSO}(5-10 \%)$ in a liquid nitrogen container. $25 \mathrm{~cm}^{2}$ tissue culture flasks containing RPMI 1640 medium i.e 10\% Fetal Bovine Serum and $2 \mathrm{nM}$ L-glutamine were used for cell lines grown and its single cell suspension was made. Tissue culture flask was then kept in a $\mathrm{CO}_{2}$ incubator at $37.5^{\circ} \mathrm{C}$ for 24-48 hrs for the purpose of cell division. Cells were counted with the help of haemocytometer and cell count is adjusted according to the titration readings (approximately $1 \times 10^{5} \mathrm{cells} / \mathrm{ml}$ ). This Cell culture was done under all aseptic condition inside the laminar flow hood to avoid bacterial contamination. Then inoculation of prepared cell suspension( $(90 \mu \mathrm{l})$ was done into 96-well Micro- Titer plates so that every well receives $5 \times 10^{3}$ cells. Then the plates were incubated at $37{ }^{\circ} \mathrm{C}, 95 \%$ air, $5 \% \mathrm{CO}_{2}$, and relative humidity $(100 \%)$ for $24 \mathrm{~h}$ prior to addition of experimental drugs. Study drug was solubilized in DMSO i.e. Dimethyl sulfoxide at $100 \mathrm{mg} /$ $\mathrm{ml}$ and diluted to $1 \mathrm{mg} / \mathrm{ml}$ using water and stored frozen prior to use.(17)

By Drug dispensing machine aliquots of $10 \mu 1$ of the study drug dilution were added to in 96 well plates which previously containing of Cell suspension $(90 \mu \mathrm{l})$ in triplicate. DMSO $(10 \mathrm{ml}$ of $10 \% \mathrm{v} / \mathrm{v})$ was added into each negative-control well and $10 \mathrm{ml}$ Adriamycin was added into each positive-control well. Drug was tested at 4 dose levels $(40,80,120,160 \mu \mathrm{g} / \mathrm{ml})$. Each experiment was repeated thrice. Then Cell fixation was done by $25 \mu 1$ cold $50 \%$ (wt/vol) TCA(Trichloroacetic acid) and plates incubation was done at for $1 \mathrm{~h}$ at $4{ }^{\circ} \mathrm{C}$. Then plates was stained by SRB dye $(50 \mu \mathrm{l})$ of $0.04 \%$ (wt $/ \mathrm{vol})$ SRB solution to each well and left for 15minutes. Then washing of the plates with tap water was done to remove SRB dye. The unbound dye was washed by $1 \%$ acetic acid and plates were dried. Then protein-bound dye was solubilized after $30 \mathrm{~min}$ in Tris base solution. Then absorbance was read on the Elisa-Plate Reader at the wavelength of $540 \mathrm{~nm}$ with reference to $690 \mathrm{~nm}$. Graphs were plotted and results was given in terms of GI50, TGI, LC50 values. Then optical density of control cells was compared to that of drug treated cells and growth inhibition calculated as values in percentage. Using the six absorbance measurements [time zero(Tz), control growth $(\mathrm{C})$ and the test growth in the presence of drug at the four concentration levels (Ti)], the percentage growth was calculated at each of the drug concentration levels. On a plate by plate basis percentage growth was calculated for test wells relative to control wells. Percent growth was expressed as the ratio of average absorbance of the test well to the average absorbance of control wells. It was calculated as $[(\mathrm{Ti}-\mathrm{Tz}) / \mathrm{C}-\mathrm{Tz})] \mathrm{x}$ 100 for concentration for which $\mathrm{Ti}>/=\mathrm{Tz}(\mathrm{Ti}-\mathrm{Tz})$ positive or zero $[(\mathrm{Ti}-\mathrm{Tz}) / \mathrm{Tz})]$ x 100 for concentration for which $\mathrm{Ti}<\mathrm{Tz}$. (Ti-Tz) negative. Growth inhibition of $50 \%$ (GI50) was calculated from [(Ti-Tz)/ C-Tz) $] \times 100=50$, which was the drug concentration resulting in a $50 \%$ reduction in the net protein increase (as measured by SRB staining) in control cells during the drug incubation. The drug concentration resulting in total growth inhibition(TGI) was calculated from $\mathrm{Ti}=\mathrm{Tz}$. The LC50 (concentration of drug resulting in a 50\% reduction in the measured protein at the end of the drug treatment as compared to that at the beginning) indicating a net loss of cells following treatment was calculated from $[(\mathrm{Ti}-\mathrm{Tz}) / \mathrm{Tz})] \times 100=-50 .(18,19)$ 


\section{Observations and Results}

The result of anticancer study on selected cancer cell lines are as follows:

Table no 1: \% Control growth of human hepatoma cell line HEPG2:

Human Hepatoma Cell Line HEPG2

$\%$ Control Growth

Drug Concentrations $(\mu \mathrm{g} / \mathrm{ml})$

\begin{tabular}{|c|c|c|c|c|c|c|c|c|c|c|c|c|c|c|c|c|}
\hline & \multicolumn{4}{|c|}{ Experiment 1} & \multicolumn{4}{|c|}{ Experiment 2} & \multicolumn{4}{|c|}{ Experiment 3} & \multicolumn{4}{|c|}{ Average Value } \\
\hline & 40 & & 120 & 160 & 40 & 80 & 120 & 160 & 40 & & 120 & & 40 & 80 & 120 & 1 \\
\hline & & & & & & & & & & & & & & & & \\
\hline & 35.2 & -48.0 & -54.4 & -57.0 & -42.4 & -47.7 & -60.7 & -61.4 & -45.3 & -49.4 & -63.1 & -65.1 & -40.9 & -48.4 & -59.4 & \\
\hline
\end{tabular}

Table no 2: \% Control growth of human prostate cell line- DU-145

Human Prostate Cancer Cell Line DU145

$\%$ Control Growth

Drug Concentrations $(\mu \mathrm{g} / \mathrm{ml})$

\begin{tabular}{|c|c|c|c|c|c|c|c|c|c|c|c|c|c|c|c|c|}
\hline & \multicolumn{4}{|c|}{ Experiment 1} & \multicolumn{4}{|c|}{ Experiment 2} & \multicolumn{4}{|c|}{ Experiment 3} & \multicolumn{4}{|c|}{ Average Values } \\
\hline & 40 & 80 & 120 & 160 & 40 & 80 & 120 & 160 & 40 & 80 & 120 & 160 & 40 & 80 & 120 & 160 \\
\hline KG & 100.0 & 95.5 & 82.0 & 78.0 & 100.0 & 98.0 & 84.7 & 80.4 & 100.0 & 96.2 & 95.8 & 86.0 & 100.0 & 96.6 & 87.5 & 81.5 \\
\hline ADR & 10.6 & 9.8 & 8.5 & 2.7 & 9.5 & 6.6 & 4.0 & 1.4 & 10.2 & 9.3 & 6.1 & 5.9 & 10.1 & 8.6 & 6.2 & 3.3 \\
\hline
\end{tabular}

Table no 3: \% Control growth of human prostate cell line PC3

Human Prostate Cancer Cell Line PC3

$\%$ Control Growth

Drug Concentrations ( $\mu \mathrm{g} / \mathrm{ml})$

\begin{tabular}{|c|c|c|c|c|c|c|c|c|c|c|c|c|c|c|c|c|} 
& \multicolumn{4}{c}{ Experiment 1 } & \multicolumn{4}{c|}{ Experiment 2 } & \multicolumn{4}{c|}{ Experiment 3 } & \multicolumn{4}{c|}{ Average Values } \\
& $\mathbf{1 0}$ & $\mathbf{2 0}$ & $\mathbf{4 0}$ & $\mathbf{8 0}$ & $\mathbf{1 0}$ & $\mathbf{2 0}$ & $\mathbf{4 0}$ & $\mathbf{8 0}$ & $\mathbf{1 0}$ & $\mathbf{2 0}$ & $\mathbf{4 0}$ & $\mathbf{8 0}$ & $\mathbf{1 0}$ & $\mathbf{2 0}$ & $\mathbf{4 0}$ & $\mathbf{8 0}$ \\
\hline KG & 100.0 & 100.0 & 98.8 & 98.7 & 100.0 & 100.0 & 99.0 & 93.2 & 100.0 & 96.3 & 94.9 & 90.8 & 100.0 & 98.8 & 97.6 & 95.3 \\
\hline ADR & -69.1 & -67.5 & -76.3 & -78.3 & -67.5 & -73.7 & -73.9 & -77.3 & -68.7 & -71.6 & -74.4 & -78.6 & -68.5 & -70.9 & -74.8 & -78.1
\end{tabular}

Table no 4: \% Control growth of human ovarian cell line PA-1

Human Ovarian Cancer Cell Line PA-1

$\%$ Control Growth

Drug Concentrations $(\mu \mathrm{g} / \mathrm{ml})$

\begin{tabular}{c|c|c|c|c|c|c|c|c|c|c|c|c|c|c|c|c|} 
& \multicolumn{4}{c}{ Experiment 1 } & \multicolumn{4}{c|}{ Experiment 2 } & \multicolumn{4}{c|}{ Experiment 3 } & \multicolumn{4}{c|}{ Average Values } \\
& $\mathbf{4 0}$ & $\mathbf{8 0}$ & $\mathbf{1 2 0}$ & $\mathbf{1 6 0}$ & $\mathbf{4 0}$ & $\mathbf{8 0}$ & $\mathbf{1 2 0}$ & $\mathbf{1 6 0}$ & $\mathbf{4 0}$ & $\mathbf{8 0}$ & $\mathbf{1 2 0}$ & $\mathbf{1 6 0}$ & $\mathbf{4 0}$ & $\mathbf{8 0}$ & $\mathbf{1 2 0}$ & $\mathbf{1 6 0}$ \\
KG & 100.0 & 100.0 & 100.0 & 100.0 & 100.0 & 100.0 & 100.0 & 100.0 & 100.0 & 100.0 & 100.0 & 95.6 & 100.0 & 100.0 & 100.0 & 98.5 \\
\hline ADR & 2.3 & -7.3 & -33.6 & -33.7 & -26.7 & -32.8 & -47.5 & -51.8 & -21.0 & -33.9 & -35.3 & -43.8 & -15.1 & -24.7 & -38.8 & -43.1
\end{tabular}

Table no 5: \% Control growth of human Ovarian cell line OVCAR-3

Human Ovarian Cancer Cell Line Ovear-3

$\%$ Control Growth

Drug Concentrations $(\mu \mathrm{g} / \mathrm{ml})$

\begin{tabular}{|c|c|c|c|c|c|c|c|c|c|c|c|c|c|c|c|c|}
\hline & \multicolumn{4}{|c|}{ Experiment 1} & \multicolumn{4}{|c|}{ Experiment 2} & \multicolumn{4}{|c|}{ Experiment 3} & \multicolumn{4}{|c|}{ Average Values } \\
\hline & 40 & & & 16 & 40 & & 120 & 16 & & & & & 40 & 80 & & 160 \\
\hline & & & & & & & & & & & & & & & & \\
\hline & -17.6 & -41.6 & -48.8 & -50.2 & -36.0 & -44.0 & -46.2 & -48.1 & -39.5 & -46.0 & -47.3 & -47.8 & -31.0 & -43.9 & -47.4 & \\
\hline
\end{tabular}

Table no 6 : \% Control growth of human ovarian cell line A2780

Human Ovarian Cancer Cell Line A2780

$\%$ Control Growth

Drug Concentrations $(\mu \mathrm{g} / \mathrm{ml})$

\begin{tabular}{|c|c|c|c|c|c|c|c|c|c|c|c|c|c|c|c|c|}
\hline & \multicolumn{4}{|c|}{ Expe } & \multicolumn{4}{|c|}{ Experiment 2} & \multicolumn{4}{|c|}{ Experiment 3} & \multicolumn{4}{|c|}{ Average Values } \\
\hline & 40 & & & & 40 & 80 & 120 & & 40 & 80 & & & 40 & 80 & 120 & \\
\hline & 0.0 & 00.0 & 100. & 100. & 000 & & 97 & & 00.0 & 00 & & & 00.0 & 99.8 & & \\
\hline & -34.0 & -35.7 & -41.2 & -48.0 & -29.3 & -31.2 & -42.4 & -50.9 & -31.9 & -33.3 & 47.6 & -54.2 & 31.7 & 33.4 & -43.8 & \\
\hline
\end{tabular}

Table no 7: \% Control growth of human ovarian cell line SK-OV-3

Human Ovarian Cancer Cell Line SK-OV-3

$\%$ Control Growth

Drug Concentrations $(\mu \mathrm{g} / \mathrm{ml})$

\begin{tabular}{|c|c|c|c|c|c|c|c|c|c|c|c|c|c|c|c|c|}
\hline & \multicolumn{4}{|c|}{ Experiment 1} & \multicolumn{4}{|c|}{ Experiment 2} & \multicolumn{4}{|c|}{ Experiment 3} & \multicolumn{4}{|c|}{ Average Values } \\
\hline & & & & 160 & 40 & 80 & & 160 & 40 & 80 & 120 & & 40 & 80 & 120 & \\
\hline & 0 & & 10 & 100 & 100 & & 10 & 98 & 1000 & & & 100 & 100.0 & 100.0 & .0 & \\
\hline & 23.0 & -31.2 & -33.9 & -47.0 & -31.7 & -36.8 & -43.5 & -54.2 & 36.8 & 37.5 & 40.4 & 46.5 & 30.5 & 35.2 & 39.2 & \\
\hline
\end{tabular}


Table no 8 : \% Control growth of human renal cell line ACHN

Human Renal Cancer Cell Line ACHN

$\%$ Control Growth

Drug Concentrations $(\mu \mathrm{g} / \mathrm{ml})$

Experiment 1

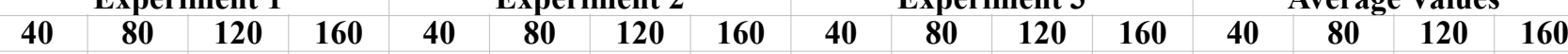

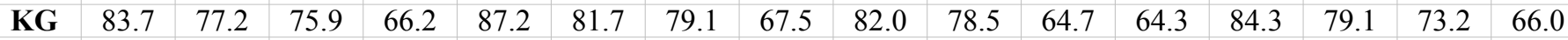

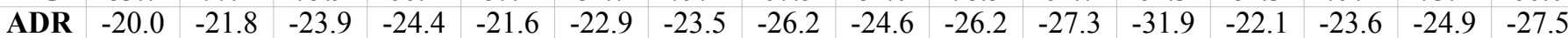

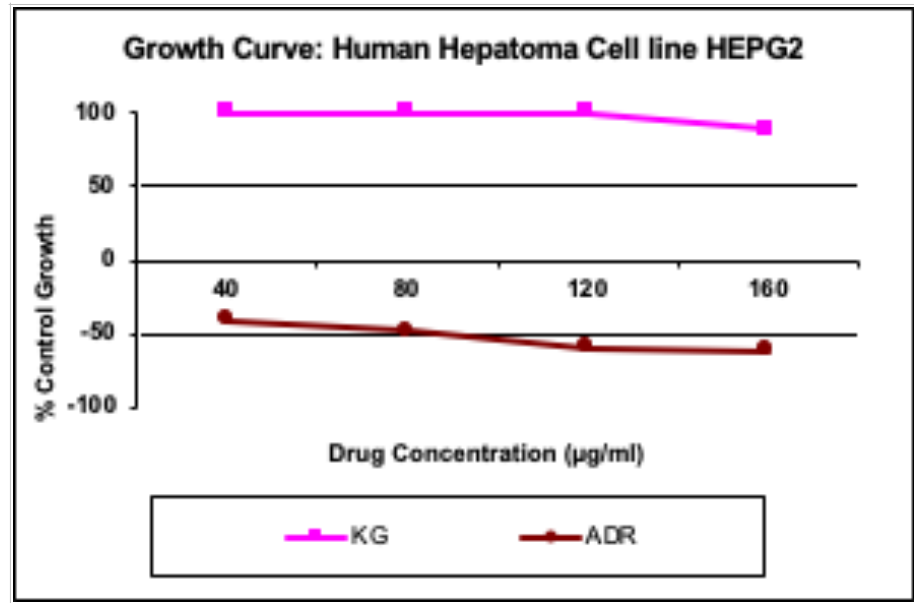

Graph no. 1: Growth curve of human hepatoma cell line HEPG2

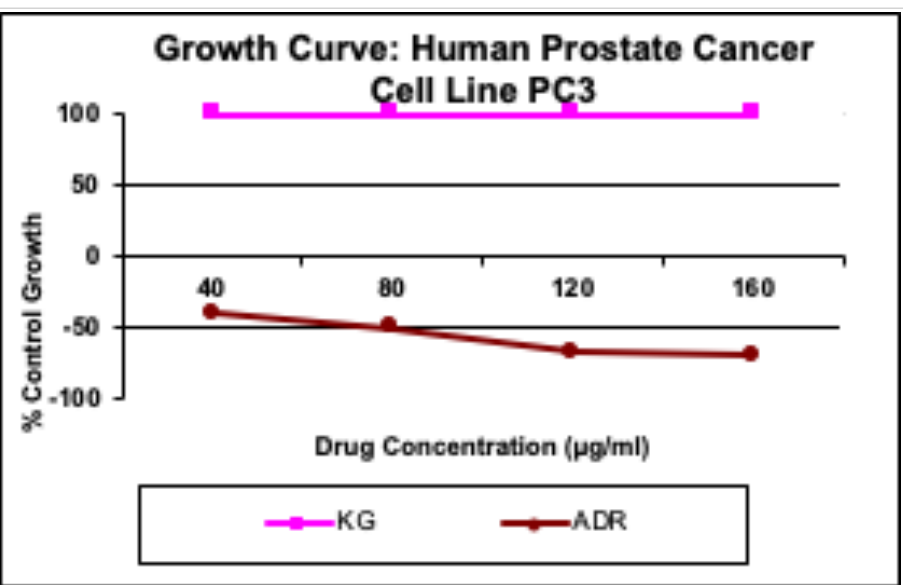

Graph no. 3: Growth curve of human prostate cell line PC3:

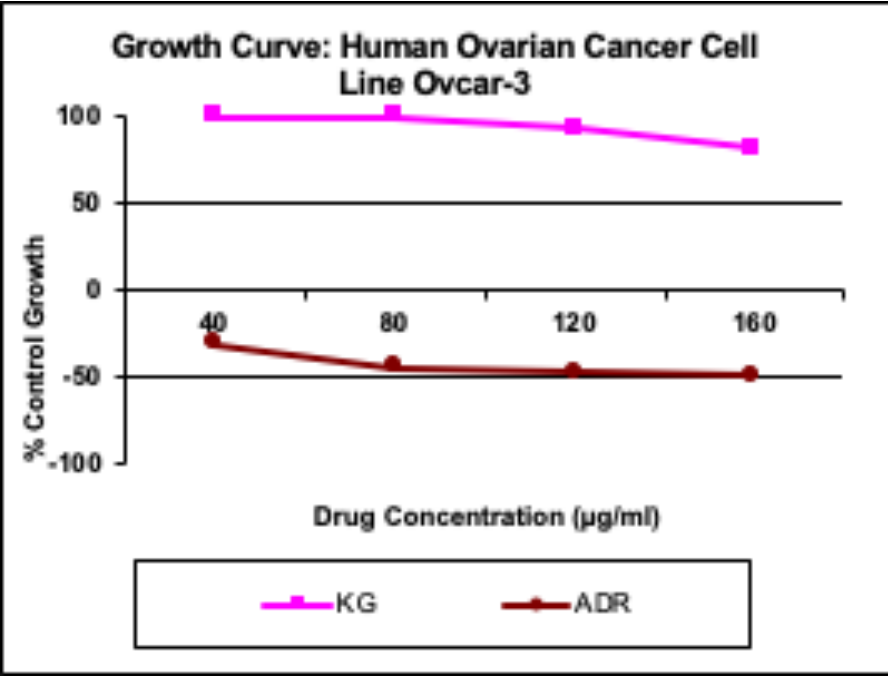

Graph no.5: Growth curve of human ovarian cell line OVCAR-3:

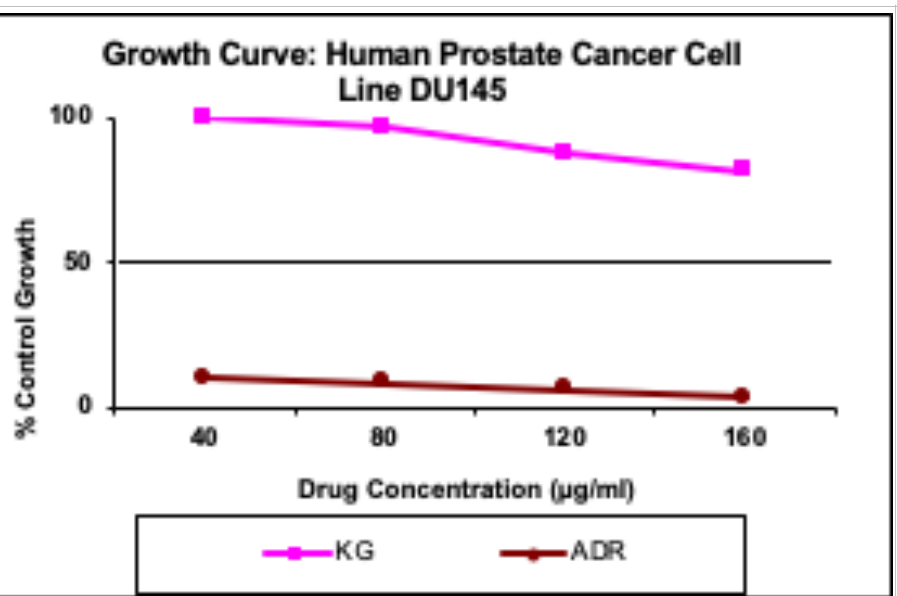

Graph no. 2: Growth curve of human prostate cell line DU145

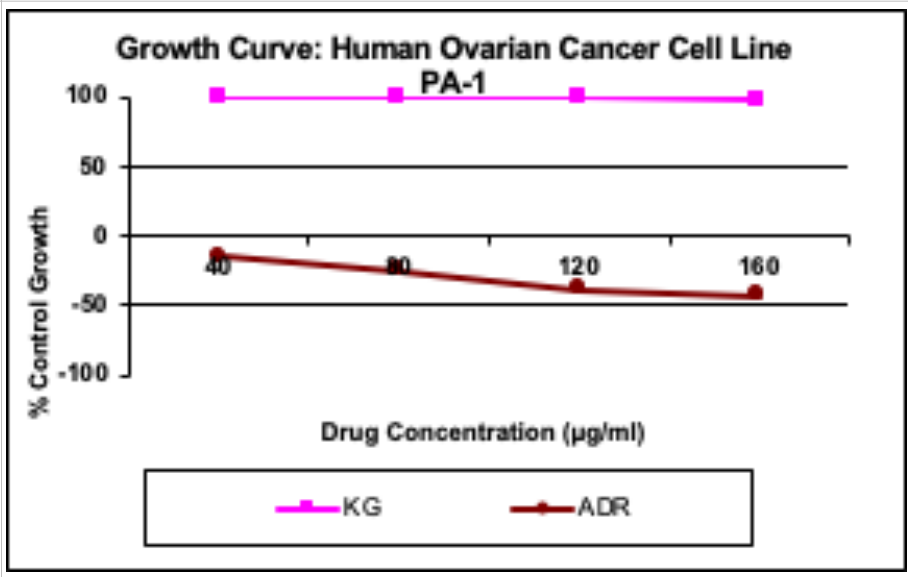

Graph no. 4: Growth curve of human ovarian cell line PA-1:

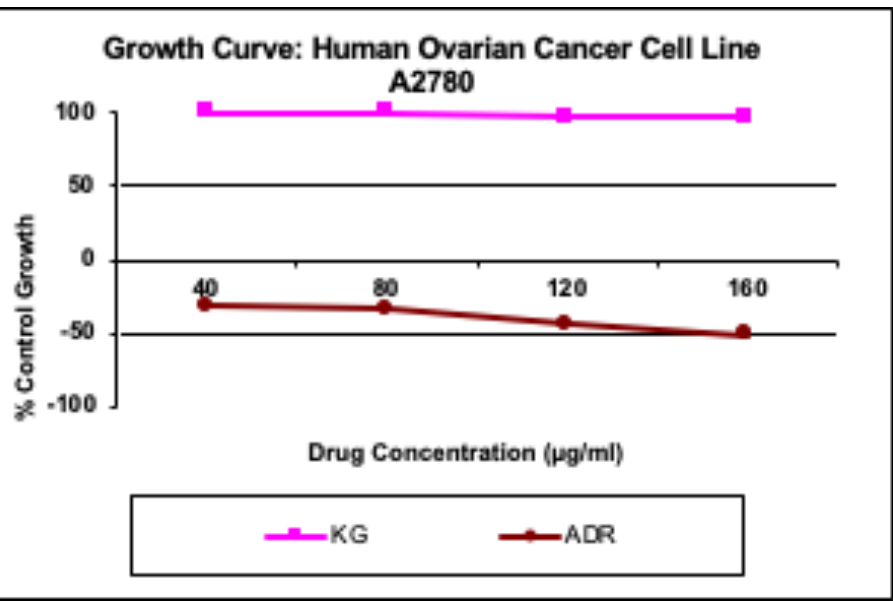

Graph no. 6: Growth curve of human ovarian cell line A2780: 


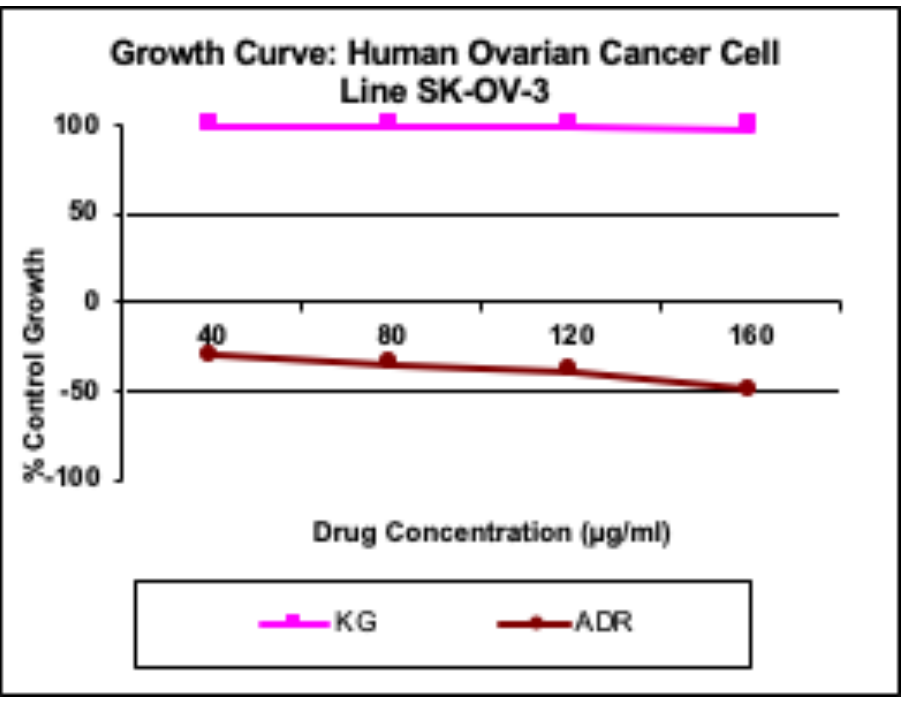

Graph no. 7: Growth curve of human ovarian cell line SK-OV-3:

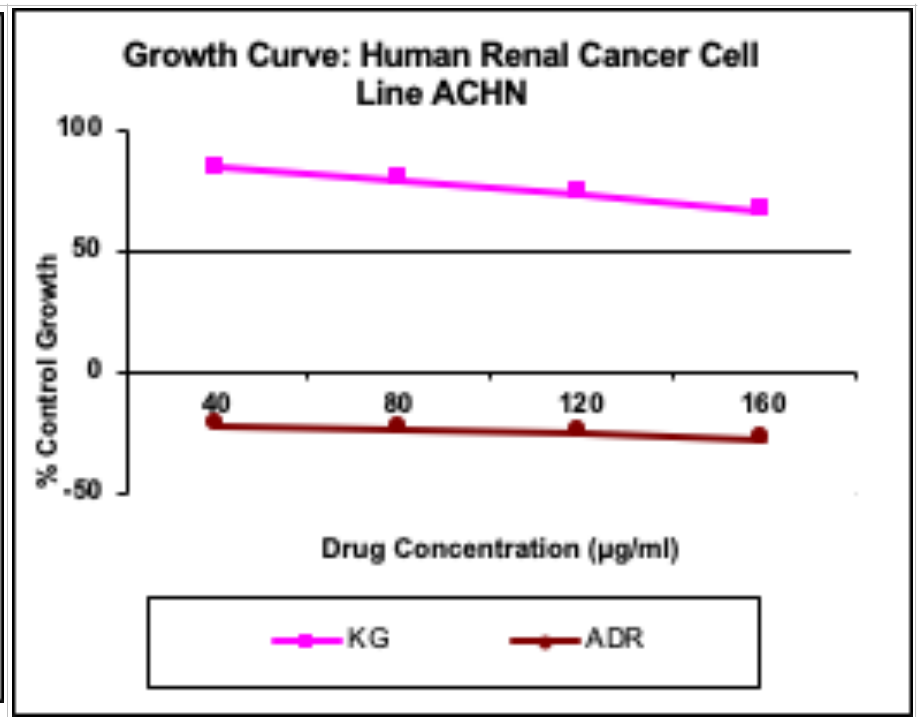

Graph no. 8: Growth curve of human renal cell line ACHN

KG: Kukkutnakhi guggul, ADR: Adriamycin

\section{Discussion}

In-vitro mechanism based screening of herbal medicine is mandatory in the preliminary phases of plant drug research before taking them to in-vivo study to evaluate their efficacy.(19) Kukkutnakhi guggula was selected for anticancer activity evaluation as it practices in tribal masses and also by senior Vaidyas in clinical practice on Galaganda (enlargement of glands of neck), Granthi(Cyst) and Arbuda (Tumor) etc. This proprietary drug prepared in teaching pharmacy by using authenticated Kukkutnakhi and Guggula in the same proportion for oral administration. In organoleptic analysis the colour of the product was found dark brown, Rasa(taste) was Tikta(Bitter) , Katu (Bitter), Kashaya(astringent) and odour was specific representing smell similar to Guggula. This is due to presence of Guggula as a major ingredients which contain few volatile phyto-constitutes having its specific odor. Triphala kwath(decoction) was used for purification of crude Guggula, as it is having proved anticancer activity. It has Tridoshas shaman and Lekhana(Scraping) properties which get embedded to purified Guggula and enhance the effect and remove the undesired effect of Guggula.

For anticancer screening of study drug, SRB (Sulphorhodamine B) assay was followed and each experiment was carried out at 4 dose levels $(40,80,120$, $160 \mu \mathrm{g} / \mathrm{ml}$ ) in a triplicate. SRB is binds to the basic amino acids of the cellular proteins as it is bright pink anionic protein staining dye and based on the measurement of cellular protein content it is mainly used for cell density determination.(19) Values obtained from optical density were estimated and average of observed values of each plate was mentioned in table and labeled as experiment 1, 2, 3 respectively. Graphs were plotted on the basis of average value obtained from each experiment which denotes the effect of study drug and control drug on selected cancer cell lines. Dye concentration was quantified by measuring absorbance at $564 \mathrm{~nm}$ and the amount of remaining cells in treated samples was compared to untreated (control) and \% inhibition of growth was determined. As per table and Graph no. 1, 2, 5 and 8 study drug had shown results in a range of 66 to 82 value of percentage control growth and inclination of line in graph. As the drug concentration increases which indicates moderate activity at maximum drug concentration i.e. $160 \mu \mathrm{g} / \mathrm{ml}$. As per table and Graph no. 3, 4, 6 and 7 study drug had shown results in range of 95-100 value of percentage control growth and very slight or no inclination in a graph at maximum concentration level i.e. $160 \mu \mathrm{g} / \mathrm{ml}$. This indicates the negligible activity, even if the concentration of drug is increased. The LC50, TGI and GI50 values of study drug were greater than $160 \mu \mathrm{g} / \mathrm{ml}$ as compared to positive control group. As LC50 values of study drug is found to be greater than $160 \mu \mathrm{g} / \mathrm{ml}$ which indicate that Kukkutnakhi Guggula is safe for oral administration and non- toxic at cellular level.

There are many advanced in-vitro screening techniques are available like SRB, MTT, Clonogenic assay, Fluorescent assays \& dye exclusion test but SRB assay is particularly useful for qualitative analysis as it is highly sensitive and give better linearity with cell number than other assay.(20,21) In cell based studies it is widely used to investigate cytotoxicity and is also high cost-effective screenings method. It was utilize to determine the selective activity of the potential anticancer drugs. $(22,23)$ There are certain limitations of SRB assay like less sensitive with non-adherent cells, several wash steps involved, but fixation required, and if drug is insoluble in solvent then it is difficult to perform assay. $(24,25,26)$ This preclinical study had shown encouraging result in the parameter of growth inhibition i.e. GI50 on particular cell lines which shows the efficacy of the drug. But there was no activity seen on some cell lines which suggest that inactivity of the study drug on cancer cell lines of particular organ. 


\section{Conclusion}

On the basis of retrospective literary review, the proprietary herbal formulation Kukkutnakhi Guggula is evaluated for its anticancer effect in 8 selected cancer cell lines. As per SRB assay protocol, Kukkutnakhi Guggula had shown moderate activity on HEPG2, ACHN, Ovcar-3 and DU145 human cancer cell lines of Liver, Renal, Ovary and Prostate organs respectively and had shown no activity on A2780, SK-OV-3, PA-1 and PC-3 cell lines. Kukkutnakhi Guggula was found safe for oral administration, non- toxic at cellular level (LC50 values were $>160$ ). This work provides scope to study its effect on targeted cancers, specific in-vivo scientific studies and human clinical trials for further researchers.

\section{Conflict of interest- Nil \\ Acknowledgement- Nil}

\section{References}

1. Greenwell M, Rahman PK. Medicinal plants: their use in anticancer treatment. International journal of pharmaceutical sciences and research. 2015 Oct 1;6(10):4103.

2. Ferlay J, Soerjomataram I, Dikshit R, Eser S, Mathers C, Rebelo M, Parkin DM, Forman D, Bray F. Cancer incidence and mortality worldwide: sources, methods and major patterns in GLOBOCAN 2012. International journal of cancer. 2015 Mar 1;136(5):E359-86.

3. Acharya YT. Sushruta Samhita of Acharya Sushruta. reprint edi. Varanasi; Chaukhambha Orientalia publishers; 2009. 159p

4. Tripathi RD. Charaka Samhita of Agnivesha; (editor), reprint edi. Varanasi; Chaukhambha Orientalia publishers; $2007.358 \mathrm{p}$

5. Ghoghari AM, Bagul MS, Anandjiwala S, Chauhan MG, Rajani M. Free radical scavenging activity of Aspidium cicutarium rhizome. Journal of Natural Remedies. 2006 Jun 1;6(2):131-4.

6. Hardik M, Nishteswar K, Patel BR, Harisha CR. Detailed Pharmacognostical Evaluation On Rhizome Of Tectaria Coadunata (Wall. Ex Hook \& Grev.) C. Chr.-A FOLKLORE HERB. Global Journal of Research on Medicinal Plants \& Indigenous Medicine. 2013 Aug 1;2(8):582.

7. Dubal KN, Ghorpade PN, Kale MV. Studies on bioactive compounds of Tectaria coadunata (Wall. Ex Hook. \& Grev.) C. Chr. Asian J Pharm Clin Res. 2013;6(2):186-7.

8. Kulkarni M, Tambe R, Bhise K. Preliminary phytochemical screening and HPTLC studies of extracts of dried rhizomes of Aspidium cicutarium. Journal of Pharmacognosy and Phytochemistry. 2013 Sep 1;2(3):50-4.

9. Sathe AP. Gharguti Aushadhe. 1st ed. Girgaon Mumbai; Ayurved Bhavan; 1922. 65p

10. Desai VG. Aushadhi Sangrah. $2^{\text {nd }}$ ed. Kothrud Pune; Rajesh Prakashan; 1975. 281p

11. Pade SS. Vanoushadhi Gunadarsh. 2nd ed Ghatkpoar Mumbai; Raghuvanshi prakashan; 1982. 306p
12. Khan MB, Sathe N, Chavan R. Commiphora mukul Engl.-"Divya": A Review. Ayurlog: National Journal of Research in Ayurved Science-2015.;3(2):1-2.

13. Gordiya RH. Ayurved patrika-Katemulee or Kombadnakhi. Nashik; Ayurveda Sewa Sangha; 1967. $115 \mathrm{p}$

14. Gokhale BV. Chikitsa pradeep. $1^{\text {st }}$ ed. Sadashiv Peth Pune; Vaidyamitra Prakashan; 1989. 74p.

15. Prabhu N. Guggul kalpana. 1st ed. Dombivali Mumbai; Karyavaha Maharashtra Ayurved Sammelan; 1999. 88p

16. Khan Mujahid B., Sathe Ninad, Deshmukh Ashwini, Rathi Bharat. Pharmaceutical study of Kukkutnakhi Guggul and its modified dosage form as tablet. Joinsysmed; 2017, vol 5(1), pp-15-20.

17. Gaidhani SN, Singh A, Kumari S, Lavekar GS, Juvekar AS, Sen S, Padhi MM. Evaluation of some plant extracts for standardization and anticancer activity. Indian Journal of Traditional Knowledge; October 2013; Vol. 12 (4), pp. 682-687

18. Skehan P, Storeng R, Scudiero D, Monks A, McMahon J, Vistica D, Warren JT, Bokesch H, Kenney S, Boyd MR. New colorimetric cytotoxicity assay for anticancer-drug screening. JNCI: Journal of the National Cancer Institute. $1990 \mathrm{Jul}$ 4;82(13):1107-12.

19. Vichai V, Kirtikara K. Sulforhodamine B colorimetric assay for cytotoxicity screening. Nature protocols. 2006 Aug;1(3):1112-6..

20. Lovitt CJ, Shelper TB, Avery VM. Advanced cell culture techniques for cancer drug discovery. Biology. 2014 Jun;3(2):345-67

21. Chanda S, Nagani K. In vitro and in vivo methods for anticancer activity evaluation and some Indian medicinal plants possessing anticancer properties: an overview. Journal of pharmacognosy and phytochemistry. 2013 Jul 1;2(2).

22. Patil LE, Kulkarni KI, Khanvilkar VI, Kadam V. In vitro evaluation of herb-drug interactions: a review. Int J Pharm Pharm Sci. 2014;6:9-12.

23. Itharat A, Houghton PJ, Eno-Amooquaye E, Burke PJ, Sampson JH, Raman A. In vitro cytotoxic activity of Thai medicinal plants used traditionally to treat cancer. Journal of ethnopharmacology. 2004 Jan 1;90(1):33-8.

24. Houghton P, Fang R, Techatanawat I, Steventon G, Hylands PJ, Lee CC. The sulphorhodamine (SRB) assay and other approaches to testing plant extracts and derived compounds for activities related to reputed anticancer activity. Methods. 2007 Aug 1;42(4):377-87.

25. Chavan R, Khan M, Sathe N, Mankar NA. A Review: SRB Assay for Screening Anticancer Activity of Herbal drugs (in-Vitro). International Ayurvedic Medical Journal. 2016;4(2):66-70.

26. Keepers YP, Pizao PE, Peters GJ, van Ark-Otte J, Winograd B, Pinedo HM. Comparison of the sulforhodamine B protein and tetrazolium (MTT) assays for in vitro chemosensitivity testing. European Journal of Cancer and Clinical Oncology. 1991 Jul 1;27(7):897-900. 